\title{
ANALISIS KESENJANGAN PERENCANAAN DAN PELAKSANAAN PEMBELAJARAN KURIKULUM 2013 DI SDN 4 KAMPUNG BARU
}

\author{
I Gede Dharma Putra, Putu Nanci Riastini \\ Jurusan Pendidikan Guru Sekolah Dasar, Fakultas Ilmu Pendidikan \\ Universitas Pendidikan Ganesha, Jln. Udayana No. 11 Singaraja \\ e-mail: uzumakigede2607@gmail.com
}

\begin{abstract}
This research goals to know the size the discrepancy lesson plan of curriculum 2013 that were created by teachers SD Negeri 4 Kampung Baru with Permendikbud No. 103 of 2014, know the size of the discrepancy learning of curriculum 2013 conducted by the teachers SD Negeri 4 Kampung Baru with Permendikbud No. 103 of 2014, and describe the factors that cause the discrepancy. This type of research is evaluative research. Subjects in this research are all teachers in SD Negeri 4 Kampung Baru. The object of research was the plan and the implementation of learning curriculum in 2013 formulated and implemented by teachers based Permendikbud No. 103 of 2014. The collection of data in this research study conducted by the method of documentation, observation, and interviews. Data have been collected were processed using nonparametric statistical test, Wilcoxon signed levels for quantitative data and the data triangulation techniques for qualitative data, and then continued with the presentation of data, and drawing conclusions. The results showed that the magnitude of the discrepancy with a lesson plan Permendikbud No. 103 of 2014 was $14.3 \%$ belong to the category of very small (SK), the wide discrepancy with the implementation of learning Permendikbud No. 103 of 2014 was of $3.41 \%$ belong to the category of very small (SK), factors causing the discrepancy is teachers prepared lesson plan created a working group of teachers and were not analyzed further by the teacher concerned.
\end{abstract}

Keywords: Discrepancy, Lesson Planning, Learning Implementation, Permendikbud No. 104/2014.

\begin{abstract}
ABSTRAK: Penelitian ini bertujuan untuk mengetahui besarnya kesenjangan rencana pelaksanaan pembelajaran Kurikulum 2013 yang dibuat oleh guru SD Negeri 4 Kampung Baru dengan Permendikbud Nomor 103 Tahun 2014, mengetahui besarnya kesenjangan proses pembelajaran Kurikulum 2013 yang dilakukan oleh guru SD Negeri 4 Kampung Baru dengan Permendikbud Nomor 103 Tahun 2014, dan mendeskripsikan faktor penyebab terjadinya kesenjangan. Jenis penelitian ini adalah penelitian evaluatif. Subjek dalam penelitian ini yaitu seluruh guru kelas di SD Negeri 4 Kampung Baru. Objek penelitian adalah rencana dan pelaksanaan pembelajaran kurikulum 2013 yang disusun dan dilaksanakan oleh guru berdasarkan Permendikbud Nomor 103 Tahun 2014. Pengumpulan data dalam penelitian ini dilakukan dengan metode studi dokumentasi, observasi, dan wawancara. Data yang sudah terkumpul diolah dengan menggunakan statistik non parametrik dengan uji jenjang bertanda Wilcoxon untuk data kuantitatif dan teknik Triangulasi data untuk data kualitatif, kemudian dilanjutkan dengan penyajian data, dan penarikan kesimpulan. Hasil penelitian menunjukkan bahwa besarnya kesenjangan rencana pelaksanaan pembelajaran dengan Permendikbud Nomor 103 Tahun 2014 adalah sebesar 14,3\% tergolong kategori sangat kecil (SK), besarnya kesenjangan pelaksanaan pembelajaran dengan Permendikbud Nomor 103 Tahun 2014 adalah sebesar 3,41\% tergolong kategori sangat kecil (SK), Faktor penyebab kesenjangan adalah guru melupakan beberapa komponen dalam rencana pelaksanaan pembelajaran dan pelaksanaan pembelajaran dan masih ada guru kelas yang berpedoman pada permendikbud 81a tahun 2013.
\end{abstract}

Kata-kata Kunci: Kesenjangan, Perencanaan Pembelajaran, Pelaksanaan Pembelajaran, Permendikbud No. $104 / 2014$. 
Kurikulum merupakan sebuah unsur paling penting untuk menggerakkan sistem pendidikan yang ada di suatu Negara, termasuk di Indonesia. Kurikulum dipandang sebagai "suatu rencana yang disusun untuk melancarkan proses belajar-mengajar di bawah bimbingan dan tanggung jawab sekolah atau lembaga pendidikan beserta staf pengajarnya" (Nasution, 2006:5). Undang-Undang Nomor 20 Tahun 2003 tentang Sistem Pendidikan Nasional menyebutkan bahwa "kurikulum adalah seperangkat rencana dan pengaturan mengenai tujuan, isi, dan bahan pelajaran serta cara yang digunakan sebagai pedoman penyelenggaraan kegiatan pembelajaran untuk mencapai tujuan pendidikan tertentu". Mengacu pada pengertian tersebut, tampak jelas bahwa kurikulum adalah kunci dari kelacaran proses belajar mengajar di kelas.

Perkembangan kurikulum di Indonesia merupakan penjabaran amanat Undangundang Nomor 4 Tahun 1950 tentang Dasar Pendidikan dan Pengajaran, Undang-undang Nomor 12 Tahun 1954, UU Nomor 22 Tahun 1961, UU Nomor 2 Tahun 1989, dan akhirnya UU Nomor 20 Tahun 2003 tentang Sistem Pendidikan Nasional. Di samping itu, tuntutan globalisasi dan perkembangan ilmu pengetahuan serta teknologi juga ikut mendorong terjadinya perbaikan dan pengembangan kurikulum. Sejak Indonesia merdeka, negeri ini telah memiliki sekian banyak kurikulum, yakni: 1) Rencana Pelajaran 1947, 2) Rencana Pendidikan 1950, 3) Rencana Pendidikan 1958, 4) Rencana Pendidikan 1964, 5) Kurikulum 1968, 6) Kurikulum 1974, 7) Kurikulum 1978, 8) Kurikulum 1984, 9) Kurikulum 1994, 10) Kurikulum 2004, 11) Kurikulum 2006, dan 12) Kurikulum 2013 (Hidayati, 2012).

Kurikulum 2013, merupakan kurikulum yang menggunakan pendekatan pembelajaran tematik terpadu. Pendekatan tematik terpadu merupakan "pendekatan pembelajaran yang mengintegritas berbagai kompetensi dari berbagai mata pelajaran ke dalam berbagai tema" (Prastowo, 2015:29). Standar Kriteria Lulusan (SKL) menjadi rujukan ketika Kurikulum 2013 diterapkan, termasuk tujuan standar nasional pendidikan lainnya. Demikian juga dengan Kurikulum Tingkat Satuan Pendidikan (KTSP), tetap menjadi bagian Kurikulum 2013. Satuan pendidikan tetap mempunyai kewenangan untuk mengembangkan kurikulum sendiri yang sesuai dengan kondisi satuan pendidikan tersebut. Di samping itu, Kurikulum 2013 tetap merupakan pengembangan dari Kurikulum Berbasis Kompetensi.

Kurikulum 2013 merupakan rencana lanjutan pemerintah dalam menyempurnakan kurikulum yang terdahulu, yaitu Kurikulum Berbasis Kompetensi (KBK) pada tahun 2004 dan Kurikulum Tingkat Satuan Pendidikan (KTSP) pada tahun 2006 (Kurniasih \& Sani, 2014). Perubahan dari kurikulum sebelumnya pada kompetensi lulusan ditunjukkan dengan adanya peningkatan dan keseimbangan soft skills dan hard skills, yang meliputi aspek kompetensi sikap, keterampilan, dan pengetahuan. Proses pembelajaran pada kurikulum 2013 dirancang berpusat pada siswa atau dikenal dengan (student centre). Selain itu kurikulum 2013 juga menekankan pada pembelajaran kontekstual. Artinya, guru tidak hanya memanfaatkan buku sebagai sumber belajar, tetapi juga memanfaatkan kondisi nyata di sekitar siswa. Pemerintah juga menyiapkan semua komponen kurikulum sampai buku dan pedoman, termasuk penyusunan silabus dan RPP. Penerapannya tentu dibarengi dengan suatu kebijakan yang digulirkan pemerintah untuk mengatur pelaksanaan kurikulum tersebut (Permendikbud nomor 103 tahun 2014 tentang pembelajaran pada pendidikan dasar dan menengah, 2014).

Kurikulum 2013 dilaksanakan berdasarkan landasan hukum yang telah dikeluarkan oleh Kementerian Pendidikan dan Kebudayaan. Berbagai Permendikbud telah diterbitkan untuk menunjang pelaksanaan Kurikulum 2013. Salah satu Permendikbud yang menjelaskan pelaksanaan kurikulum 2013 adalah Permendikbud Nomor 103 Tahun 2014 tentang Pembelajaran pada Pendidikan Dasar dan Menengah. Peraturan ini menyangkut tata cara pelaksanaan pembelajaran. Artinya, dalam peraturan tersebut telah diatur kriteria minimal dalam melaksanakan perencanaan pembelajaran yang bisa dijadikan pedoman bagi guru-guru dalam menyusun RPP kurikulum 2013. Selain itu, diatur pula bagaimana pelaksanaan pembelajaran kuikulum 2013 yang bisa dijadikan patokan oleh guru dalam proses pembelajaran (Permendikbud nomor 103, 2014).

Aspek yang paling disoroti dalam pelaksanaan kurikurum 2013 adalah aspek 
perencanaan dan aspek pembelajaran yang sesuai dengan Permendikbud Nomor 103 Tahun 2014. Gurulah yang menjadi ujung tombak dalam tahap perencanaan dan proses pembelajaran. Meskipun guru sebagai ujung tombak, namun guru tidak serta merta dapat beradaptasi dan mengikuti tuntutan perubahan kurikulum. Perencanaan dan pelaksanaan pembelajaran yang dilakukan oleh guru kerap kali belum sesuai dengan standar proses kurikulum 2013 yang ditetapkan dalam Permendikbud Nomor 103 Tahun 2014. Hal ini dikarenakan kurangnya pemahaman terhadap konsep kurikulum. Banyak hambatan yang ditemukan dalam penerapan kurikulum 2013, sehingga pembelajaran belum bisa berjalan sesuai dengan standar.

Hal serupa juga terjadi di salah satu sekolah yang menjadi contoh pelaksanaan kurikulum 2013 di Singaraja, yaitu SD Negeri 4 Kampung Baru. Proses menjalankan kurikulum 2013 di SD Negeri 4 Kampung Baru masih memiliki beberapa masalah yang dihadapi. Masalah-masalah tersebut diantaranya (1) guru dan siswa belum terbiasa menggunakan kurikulum ini, (2) RPP guru kurang sesuai dengan permendikbud nomor 103 tahun 2014, (3) proses pembelajaran yang dilakukan guru belum sesuai dengan pemendikbud nomor 103 tahun 2014, (4) beberapa alat peraga yang ada di sekolah kurang relevan dengan materi di kurikulum 2013, (5) guru kesulitan dalam menulis rapor siswa, (6) buku siswa datangnya terlambat dari pemerintah pusat sehingga menghambat proses pembelajaran, (7) masalah biaya untuk menjalankan pembelajaran dirasa masih cukup membebani guru, (8) permendikbud yang berlaku sifatnya baru, dan (9) tidak semua guru mendapatkan pelatihan langsung dari pemerintah (hasil wawancara 28 Januari 2016).

Dari berbagai masalah yang dihadapi oleh guru di SD Negeri 4 Kampung Baru, pada penelitian ini hanya terfokus pada kesenjangan yang terjadi antara rencana pembelajaran yang dibuat oleh guru dan permendikbud nomor 103 tahun 2014, serta kesenjangan yang terjadi antara pelaksanaan pembelajaran yang dilaksanakan oleh guru dan permendikbud nomor 103 tahun 2014. Selain itu, penelitian ini juga akan mendeskripsikan lebih mendalam tentang faktor yang mempengaruhi terjadinya kesenjangan tersebut dan dampak yang ditimbulkan oleh kesenjangan pada proses pembelajaran di kelas. Dengan demikian, penelitian ini mengangkat judul "Analisis Kesenjangan Perencanaan Dan Pelaksanaan Pembelajaran Kurikulum 2013 Berdasarkan Permendikbud Nomor 103 Tahun 2013 Di Sekolah Dasar Negeri 4 Kampung Baru Tahun Pelajaran 2015/2016".

Tujuan Penelitian ini antara lain, (1) untuk mengetahui besarnya kesenjangan antara Rencana Pelaksanaan Pembelajaran (RPP) Kurikulum 2013 yang dibuat oleh guru SD N 4 Kampung Baru Tahun Pelajaran 2015/2016 dan Permendikbud Nomor 103 Tahun 2014 tentang Kurikulum 2013, (2) Untuk mengetahui besarnya kesenjangan antara proses pembelajaran Kurikulum 2013 yang dilakukan oleh guru SD N 4 Kampung Baru Tahun Pelajaran 2015/2016 dan Permendikbud Nomor 103 Tahun 2014 tentang Kurikulum 2013, dan (3) untuk mendeskripsikan faktor penyebab terjadinya kesenjangan antara rencana dan proses pelaksanaan pembelajaran berdasarkan Permendikbud Nomor 103 tahun 2014.

Hasil penelitian ini bermanfaat secara teoritik dan praktis. Dari segi teoritik, hasil penelitian ini diharapkan menambah khazanah ilmu pengetahuan tentang kurikulum 2013, pengembangan kurikulum 2013, kendalakendala pelaksanaan kurikulum 2013, dan diharapkan berkontribusi pada perbaikan pembelajaran serta kualitas pendidikan di sekolah dasar. Dari segi praktis, hasil penelitian ini bermanfaat sebagai berikut. (1) Bagi Guru, penelitian ini dapat digunakan sebagai informasi tambahan tentang besar kesenjangan yang masih terdapat dalam perencanaan dan pelaksanaan pembelajaran berdasarkan Permendikbud No. 103 tahun 2014 sehingga dapat dijadikan acuan guna perbaikan dalam merencanakan dan melaksanakan suatu pembelajaran sesuai dengan tuntunan dari peraturan pemerintah yang telah disediakan. (2) Bagi Kepala Sekolah penelitian ini memberikan sumbangan konstruktif dalam rangka peningkatan kinerja guru di sekolah. Hasil penelitian ini juga dapat menjadi masukan agar fasilitas, sarana, dan prasana yang mendukung proses pembelajaran di sekolah lebih diperhatikan. Selain itu, penelitian ini juga digunakan sebagai rujukan dalam penentuan kebijakan terkait pengembangan kemampuan guru dalam merencanakan dan melaksanakan pembelajaran. (3) Bagi Peneliti Lain, 
penelitian ini dapat digunakan sebagai rujukan bagi penelitian-penelitian sejenis lainnya, baik dalam menjalankan penelitian yang serupa

\section{METODE}

Jenis penelitian yang digunakan pada penelitian ini adalah Penelitian Evaluasi (evaluation research). Penelitian evaluasi yaitu "penelitian yang difokuskan pada suatu kegiatan dalam suatu unit (site) tertentu" (Sudaryono, dkk, 2012:8). Sejalan dengan hal tersebut, Kline (dalam Hadi \& Mutrofin, 2006) "riset evaluasi dimaksudkan untuk mengukur hasil dari suatu kebijakan, program, proyek, produk, atau aktivitas tertentu".

Penelitian ini menganalisis kesenjangan dari subjek dan objek penelitian yang ada dalam acuan dengan discrepancy model (model kesenjangan) yang dikonfimasikan dengan sasaran yang merupakan acuan (standar) suatu program. Kunci dari model kesenjangan adalah dalam hal membandingkan penampilan dengan tujuan yang telah ditetapkan. Model kesenjangan dimaksudkan untuk mengetahui tingkat kesesuaian antara kriteria yang sudah ditetapkan dalam program yang direncanakan dengan penampilan aktual dari program tersebut.

Subjek penelitian adalah sesuatu yang diteliti baik orang, benda, ataupun lembaga (organisasi). Subjek dari penelitian ini adalah rencana pelaksanaan pembelajaran yang dibuat guru, proses pembelajaran yang dilaksanakan guru, Permendikbud Nomor 103 Tahun 2014 tentang Kurikulum 2013, guru kelas 1 sampai kelas 6 SDN 4 Kampung Baru, kepala sekolah Dasar Negeri 4 Kampung Baru, dan siswa SDN 4 Kampung Baru.

Objek penelitian adalah sifat keadaan dari suatu benda, orang, atau yang menjadi pusat perhatian dan sasaran penelitian. Objek penelitian ini adalah kesenjangan antara rencana pelaksanaan pembelajaran dan Permendikbud No 103 Tahun 2014, kesenjangan proses pembelajaran di kelas dan Permendikbud No 103 Tahun 2014, faktorfaktor yang mengakibatkan terjadinya kesenjangan tersebut, dan dampak yang ditimbulkan oleh kesenjangan itu sendiri.

Pengumpulan data yang dilakukan pada penelitian ini menggunakan tiga metode yaitu, metode wawancara, metode observasi, dan ataupun mengembangkan cangkupan penelitian menjadi lebih luas.

metode studi dokumen. Metode wawancara ini akan dilaksanakan sebelum dan sesudah kegiatan observasi dilakukan. Metode ini dilakukan dengan bertanya secara langsung kepada narasumber, yaitu guru dan kepala sekolah, tentang kesiapan dalam merancang dan melaksanakan proses pembelajaran kurikulum 2013 berdasarkan permendikbud nomor 103 tahun 2014. Data yang dikumpulkan dengan metode ini adalah data yang berkaitan dengan data kualitatif berupa berbagai pengalaman guru dalam merancang dan melaksanakan pembelajaran kurikulum 2013 yang berdasarkan permendikbud nomor 103 tahun 2014. Data yang terkumpul digunakan sebagai alat untuk menganalisis faktor yang menyebabkan kesenjangan tersebut terjadi dan dampak yang timbul akibat dari kesenjangan tersebut.

Metode observasi dilakukan dengan cara observasi langsung terhadap pelaksanaan pembelajaran yang dilaksanakan oleh guru di dalam kelas. Metode ini digunakan untuk mengumpulkan data berupa angka tentang penilaian proses pembelajaran yang dilakukan guru berdasarkan permendikbud nomor 103 tahun 2014.

Metode studi dokumen dilaksanakan dengan cara mengumpulkan dokumendokumen yang menjadi objek analisis dalam penelitian ini. Dalam kegiatan studi dokumen ini, segala bentuk dokumen yang diperlukan dikumpulkan oleh peneliti untuk dianalisis.

\section{HASIL DAN PEMBAHASAN}

\section{Hasil}

Penelitian ini dilaksanakan di SDN 4 Kampung Baru, yang menerapkan Kurikulum 2013 sampai saat ini. Penelitian dilaksanakan pada rentang semester genap tahun pelajaran 2015/2016. SDN 4 Kampng Baru sudah menjadi sekolah percontohan dari tahun 2013 hingga sekarang. Saat ini, dari kelas 1 sampai kelas 6 di sekolah ini menerapkan pembelajaran kurikulum 2013.

Data penelitian dikumpulkan menggunakan instrumen lembar studi dokumen, lembar observasi, dan wawancara 
tak terstruktur. Instrumen penelitian yang digunakan terdiri dari 20 butir instrumen lembar studi dokumen perencanaan pembelajaran, 17 butir instrumen lembar observasi pelaksanaan pembelajaran, dan pedoman wawancara faktor penyebab terjadinya kesenjangan. Jumlah guru yang diteliti adalah berjumlah 10 orang guru, yang terdiri atas guru kelas 1A, 1B, 2A, 2B, 3A, 3B, 4A, 4B, 5, dan 6.

Tabel 1. Perolehan Skor Perencanaan Pembelajaran

\begin{tabular}{|c|c|c|c|c|}
\hline \multirow{2}{*}{ No } & \multirow{2}{*}{$\begin{array}{l}\text { Guru } \\
\text { Kelas }\end{array}$} & \multirow{2}{*}{$\mathrm{N}$} & \multicolumn{2}{|c|}{ RPP } \\
\hline & & & Skor & Persentase skor (\%) \\
\hline 1 & $1 \mathrm{~A}$ & 1 & 84 & 84 \\
\hline 2 & $1 \mathrm{~B}$ & 1 & 84 & 84 \\
\hline 3 & $2 \mathrm{~A}$ & 1 & 84 & 84 \\
\hline 4 & $2 \mathrm{~B}$ & 1 & 89 & 89 \\
\hline 5 & $3 \mathrm{~A}$ & 1 & 90 & 90 \\
\hline 6 & 3B & 1 & 84 & 84 \\
\hline 7 & $4 \mathrm{~A}$ & 1 & 78 & 78 \\
\hline 8 & $4 \mathrm{~B}$ & 1 & 80 & 80 \\
\hline 9 & 5 & 1 & 93 & 93 \\
\hline 10 & 6 & 1 & 91 & 91 \\
\hline \multicolumn{2}{|c|}{ Jumlah } & 10 & 857 & 857 \\
\hline \multicolumn{4}{|c|}{ Rerata } & 85,7 \\
\hline
\end{tabular}

Berdasarkan data di atas, rata-rata Perolehan perentase skor perencanaan pembelajaran yang dilaksanakan oleh semua guru kelas dari guru kelas 1A hingga guru kelas 6 sebesar 85,7. Kecenderungan yang terjadi adalah persentase skor berada pada rentangan 78-93, dengan guru kelas 4A mendapatkan persentase skor terendah yaitu 78 dan guru kelas 5 mendapatkan pesentase skor tertinggi yaitu 98 .
Perolehan persentase skor perencanaan pembelajaran kemudian disajikan ke dalam bentuk grafik, seperti terlihat pada Gambar 1 . 


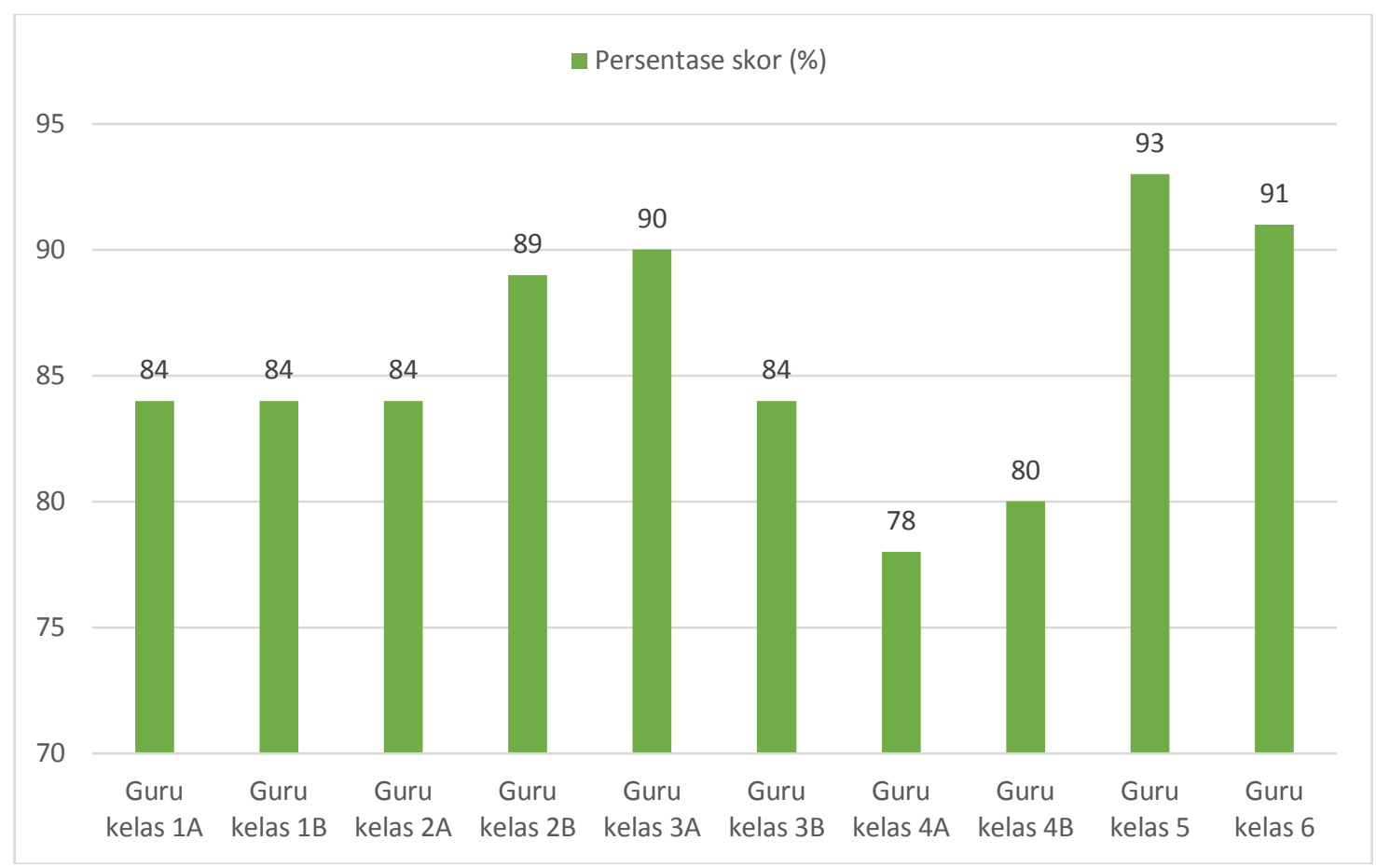

Gambar 1. Grafik Data Perolehan Persentase Skor Perencanaan Pembelajaran

Berdasarkan grafik di atas tergambar grafik yang datar di awal lalu mengalami peningkatan pada guru kelas $2 \mathrm{~B}$ dan $3 \mathrm{~A}$ kemudian mengalami penurunan yang drastis pada guru kelas $4 \mathrm{~A}$ yang merupakan titik terendah dari grafi di atas. Kemudian mengalami peningkatan kembali dan mengalami titik tertinggi di guru kelas 5 kemudian sedikit menurun di guru kelas 6 .

Tabel 2. Perolehan Skor Pelaksanaan Pembelajaran

\begin{tabular}{ccccc}
\hline \multirow{2}{*}{ No } & \multirow{2}{*}{ Guru Kelas } & \multirow{2}{*}{$\mathrm{N}$} & \multicolumn{2}{c}{ Pelaksanaan Pembelajaran } \\
\cline { 5 - 5 } & & & Skor & Persentase skor (\%) \\
\hline 1 & 1A & 1 & 81 & 95,29 \\
\hline 2 & 1B & 1 & 81 & 95,29 \\
\hline 3 & 2A & 1 & 77 & 90,59 \\
\hline 4 & 2B & 1 & 77 & 90,59 \\
\hline 5 & 3A & 1 & 81 & 95,29 \\
\hline 6 & 3B & 1 & 85 & 100 \\
\hline 7 & 4A & 1 & 85 & 100 \\
\hline 8 & 4B & 1 & 85 & 100 \\
\hline 9 & 5 & 1 & 85 & 100 \\
\hline 10 & 6 & 1 & 84 & 98,82 \\
\hline & Jumlah & 10 & 821 & 965,87 \\
\hline
\end{tabular}

Berdasarkan data di atas, rata-rata perolehan skor pelaksanaan pembelajaran yang dilaksanakan oleh semua guru dari guru kelas 1A hingga guru kelas 6 sebesar 96,59. Kecenderungan yang terjadi adalah persentase skor berada pada rentangan 90,59-100, dengan guru kelas 2A dan 2B mendapatkan persentase skor terendah yaitu 90,59 dan guru kelas 3B, 4A, 4B, dan 5 mendapatkan pesentase skor tertinggi yaitu 100. Perolehan persentase skor perencanaan pembelajaran kemudian disajikan ke dalam bentuk grafik, seperti terlihat pada Gambar

2. 


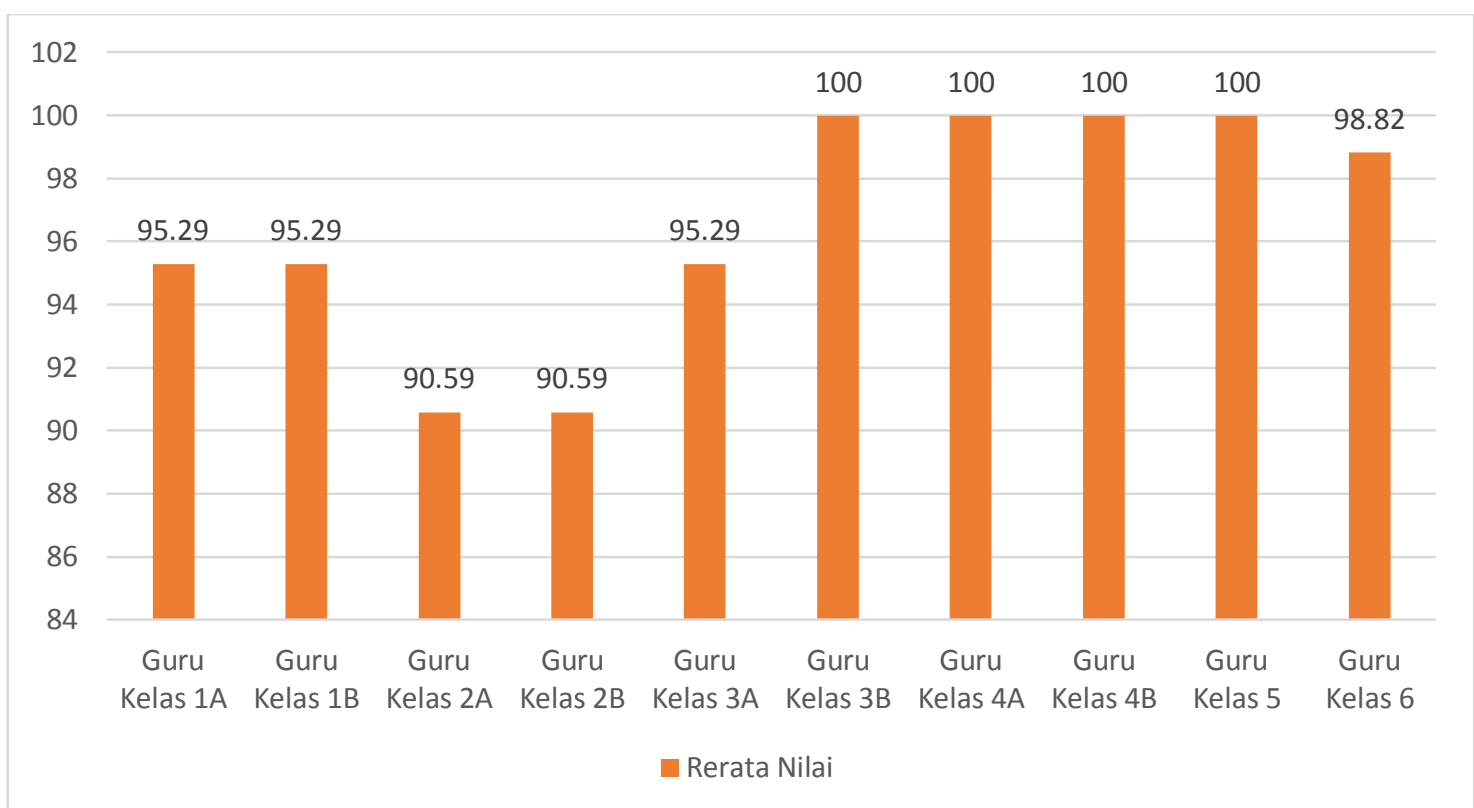

Gambar 2 Grafik Data Perolehan Skor Pelaksanaan Pembelajaran

Berdasarkan grafik di atas tergambar grafik yang datar di awal lalu mengalami penurunan pada guru kelas 2A dan kelas 2B yang merupakan titik terendah dari grafik di atas. Kemudian mengalami peningkatan pada guru kelas 3A dan pada guru kelas 3B meingkat lagi yang menjadi titik paling tinggi dan menurun kembali pada guru kelas 6 .

Setelah dilaksanakan analisis data dan ditemukan beberapa kesenjangan yang dilaksanakan oleh guru SDN 4 Kampung Baru, langkah berikutnya adalah melaksanakan wawancara tidak terstruktur tentang beberapa kesenjangan yang dilakukan oleh guru untuk mencari faktor penyebab terjadinya kesenjangan. Adapun berbagai temuan yang didapatkan dari wawacara tersebut antara lain, (1) guru tidak mencantumkan KI-1 dan KI-2 karena KI-1 dan KI-2 sudah ada pada buku dan bahasanya juga sama saja, jadi tidak mesti di buat. Selanjutnya ada juga guru yang lupa mencantumkannya. Ada juga guru mengatakan bahwa RPP yang ia gunakan masih berpatokan pada pedoman yang lama. (2) Guru berpendapat "dengan butir materi itu saja sudah menggambarkan keseluruhan materi pembelajaran, materi yang lebih rinci sudah ada di buka paket". Ada juga guru mengatakan bahwa "itu sudah sesuai dengan permendikbud 104 tahun 2014 dan permendikbud 81A tahun 2013".

(3) Respon para guru yang tidak mencantumkan jenis kegiatan 5M pada langkah pembelajaran, yaitu sudah kesepakatan bersama dengan guru-guru lain saat menyusun RPP, karena pada langkah pembelajaran sudah mengacu pada langkah pendekatan saintifik, ada juga guru yang lupa mencantumkannya. (4) Respon guru yang tidak menggunakan lingkungan sebagai sumber belajar siswa sebagai berikut; guru merasa sudah menggunakan lingkungan; tergantung dengan materi yang ada di buku, jika materi mengharapkan menggunakan lingkungan, pada saat itu menggunakannya; keterbatasan waktu yang tidak memungkinkan menggunakan lingkungan; dan keterbatasan ruang yang ada di sekolah sebagai sumber belajar siswa.

(5) Respon guru yang tidak mencantumkan alokasi waktu pada langkah pembelajaran yaitu, guru kadang merasa kebablasan dengan alokasi yang dicantumkan tersebut, juga guru mengatakan sudah merancang sedemikian rupa, dan ada juga guru yang mengaku lupa mencantumkan. (6) IPTEK masih terbatas di sekolah dan belum semua guru mampu menggunakannya, keterbatasan waktu mencari media dan keterbatasan penggunaannya, selai itu ada juga guru yang bersikeras bahwa sudah mencantumkan iptek, namun kenyataanny tidak mencantumkan.

(7) Guru lupa melakukan apersepsi dan guru berpendapat bahwa apersepsi dapat dilakukan dalam bentuk apa saja sebagai 
contoh mengatur tempat duduk dan mengabsen secara global juga termasuk apersepsi. (8) Guru mengatakan "butuh waktu yang cukup lama untuk memberikan penilaian terhadap hasil belajar siswa" sehingga guru tidak melaksanakan penilaian pada saat itu juga.

(9) Guru tidak menyampakan pembelajaran berikutnya karena sudah mengarahkan siswa untuk mengerjakan tugas rumah yang ada di buku, guru lupa, dan kalau disampaiakan anak atau siswa akan merasa jenuh dan tidak mau belajar dalam kegiatan pembelajaran berikutnya. Selanjutnya ada juga guru yang merasa sudah melaksanakannya namun kenyataannya memang tidak dilaksanakan.

\section{Pembahasan}

Berdasarkan hasil penelitian yang telah didapat dan dianalisis, kesenjangan yang terjadi di SDN 4 Kampung Baru yang menyangkut rencana pelaksanaan pembelajaran paling banyak dilakukan oleh guru, yaitu tentang merancang penggunaan lingkungan sekitar sebagai sumber belajar bagi siswa dengan besar kesenjangan yang mencapai angka 64\% dengan ketegori kesenjangan besar (B). Selain merancang lingkungan sekitar sebagai sumber belajar, komponen yang mengalami kesenjangan antara lain: (1) Kompetensi Dasar harus memuat secara utuh kompetensi dasar sikap spiritual (KD dari KI-1), sosial (KD dari KI2), pengetahuan (KD dari KI-3), dan ketrampilan (KD dari KI-4), (2) Mencantumkan indikator pencapaian kompetensi dan dirumuskan berdasarkan kompetensi dasar, (3) Materi pembelajaran memuat fakta, konsep, prinsip, dan prosedur vang relevan, (4) Materi pembelajaran ditulis dalam bentuk butir-butir sesuai dengan rumusan indikator pencapaian kompetensi, (5) Kegiatan pembelajaran sesuai dengan pendekatan pembelajaran saintifik dan menggunakan pembelajaran inovatif. (6) Dalam masing-masing kegiatan pembelajaran dicantumkan alokasi waktu yang sudah direncanakan. (7) Mencantumkan teknik penilaian, instrument penilaian dan pembelajaran remedial dan pengayaan. (8) Mencamtumkan penerapan teknologi informasi dan komunikasi secara terintegrasi, sistematis, dan efektif sesuai dengan situasi dan kondisi. Namun kesenjangan tersebut masih masuk dalam rentangan kategori kesenjangan sangat kecil (SK) sampai kategori cukup besar (CB). Dalam implementasinya guru seharusnya merancang agar lingkungan sekitar menjadi sumber belajar bagi siswa dalam kegiatan belajar siswa, sehingga mampu menciptakan pembelajaran yang kontekstual bagi siswa. Hal tersebut sejalan dengan pendapat Kurniasih (2014) yaitu, keunggulan dari implementasi kurkulum 2013 adalah pembelajaran yang kontekstual. Hal serupa juga dicantumkan dalam permendikbud nomor 103 tahun 2014 tentang Pembelajaran Pada Pendidikan Dasar Dan Pendidikan Menengah (2014) yaitu, pembelajaran harusnya dirancang berbasis konteks dengan proses pembelajaran yang menjadikan lingkungan sekitarnya sebagai sumber belajar.

Berdasarkan hasil penelitian yang telah didapat dan dianalisis, kesenjangan yang terjadi di SDN 4 Kampung Baru yang menyangkut proses pelaksanaan pembelajaran paling banyak dilakukan oleh guru, yaitu tentang pendidik menyampaikan rencana pembelajaran pada pertemuan berikutnya dengan besar kesenjangan mencapai $40 \%$ yang tergolong dalam kategori kesenjangan kecil (K). Selain kesenjangan tersebut, bentuk kesenjangan lain yang dilakukan oleh guru, yaitu (1) Memberikan apersepsi terkait dengan kompetensi yang sudah dipelajari dan dikembangkan sebelumnya yang berkaitan dengan kompetensi yang akan dipelajari dan dikembangkan, (2) Pendidik melakukan penilaian terhadap hasil belajar siswa. Dalam kegiatan pembelajaran kueikulum 2013 guru seharusnya menyampaikan kegiatan pembelajaran yang akan siswa dapatkan selanjutnya, yang nntinya bertujuan agar siswa mampu menyiapkan diri secara fisik dan mental sebelum mendapatkan pembelajaran di esok harinya dan juga siswa memiliki waktu untuk mempersiapkan apa saja yang harus dibawa untuk mengikuti kegiatan pembelajaran di sekolah. Hal tersebut tercantum pada permendikbud nomor 104 tahun 2014 tentang Pembelajaran Pada Pendidikan Dasar Dan Pendidikan Menengah (2014) yaitu kegiatan guru dalam penutup dalam pembelajaran salah satunya adalah menyampaikan rencana pembelajaran pada pertemuan berikutnya.

Setelah didapatkan data penelitian dan dianalisis, terjadi beberapa kesenjangan 
tentang perencanaan dan pelaksanaan pembelajaran kurikulum 2013 di SDN 4 Kampung Baru, selanjutnya dilakukan wawancara untuk mencari faktor-faktor yang menyebabkan terjadinya kesenjangan. Berdasarkan hasil wawancara cenderung guru melupakan beberapa komponen dalam rencana pelaksanaan pembelajaran dan pelaksanaan pembelajaran yang sesuai dengan permendikbud nomor 103 tahun 2014 yang sedang berlaku. Selain itu ada juga guru kelas yang masih berpedoman pada permendikbud 81a tahun 2013. Berbagai faktor tersebut terjadi dikarenakan guru yang kurang adaptif dalam perubahan kurikulum yang terjadi dan ada beberapa temuan lain yaitu guru kelas di SDN 4 Kampung baru, ada yang merupakan lulusan dari S1 Bahasa Inggris dan kurang sesuai dengan kemampuan jika ia menjadi guru kelas di SD. Seharusnya seluruh guru kelas di SD merupakan lulusan yang memiliki kompetensi penuh sebagai guru sekolah dasar, karena guru merupakan pekerjaan yang termasuk dalam pekerjaan yang memiliki kompetensi professional. Hal ini sejalan dengan pendapat Kurniasih (2014) seorang guru hendaknya memiliki capability yaitu memiliki kemampuan dalam bidang ilmu yang diajarkannya dan memiliki kemampuan teoritik tentang mengajar yang baik.

\section{SIMPULAN}

Berdasarkan hasil analisis data dan pembahasan dapat disimpulkan hal-hal sebagai berikut. (1) Besarnya kesenjangan antara rencana pelaksanaan pembelajaran kurikulum 2013 yang dibuat oleh guru SD Negeri 4 Kampung Baru tahun pelajaran 2015/2016 dan Permendikbud nomor 103 tahun 2014 adalah $14,3 \%$ yang termasuk kategori sangat kecil. (2) Besarnya kesenjangan antara proses pembelajaran kurikulum 2013 yang dilaksanakan oleh guru SD Negeri 4 Kampung Baru tahun pelajaran 2015/2016 dan
Permendikbud nomor 103 tahun 2014 adalah $3,41 \%$ yang termasuk kategori sangat kecil. (3) Selanjutnya berdasarkan hasil wawancara dengan guru di SDN 4 Kampung Baru, didapatkan beberapa faktor yang mempengaruhi terjadinya kesenjangan antara lain, guru melupakan beberapa komponen dalam rencana pelaksanaan pembelajaran dan pelaksanaan pembelajaran yang sesuai dengan permendikbud nomor 103 tahun 2014 yang sedang berlaku. Selain itu ada juga guru kelas yang masih berpedoman pada permendikbud 81a tahun 2013.

\section{DAFTAR RUJUKAN}

Hadi, S. dan Mutrofin. 2006. Pengantar Metode Riset Evaluasi. Yogyakarta: Laksbang Pressindo.

Hidayati, W. 2012. Pengembangan Kurikulum. Jakarta: Pedagogia.

Kurniasih, I. dan Sani, B. 2014. Sukses Mengimplementasikan Kurikulum 2013. Yogyakarta: Kata Pena.

Nasution, S. 2006. Kurikulum dan Pengajaran. Bandung: Bumi Aksara.

Prastowo, A. 2015. Menyusun Rencana Pelaksanaan Penbelajaran (RPP) Tematik Terpadu Implementasi Kurikulum 2013 Untuk SD/MI. Jakarta: Kencana.

Peraturan Menteri Pendidikan dan Kebudayaan Republik Indonesia Nomor 103 Tahun 2014 Tentang Pembelajaran pada Pendidikan Dasar dan Pendidikan Menengah.

Sudaryono, dkk. 2012. Pengembangan Instrumen Penelitian Pendidikan. Tangerang: Graha Ilmu. 